
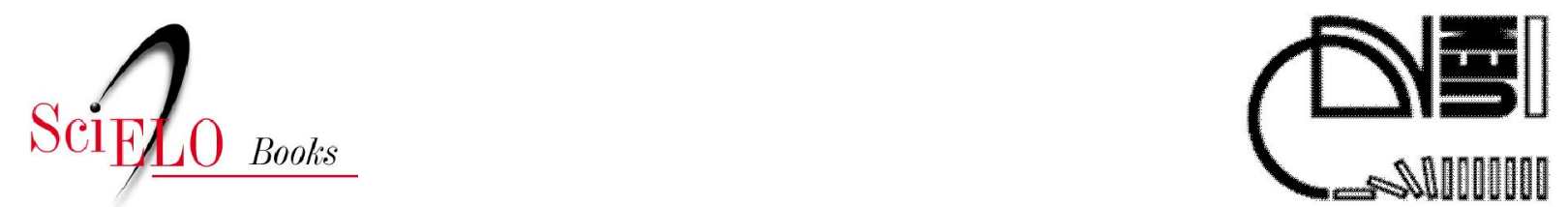

\title{
13 A Igreja Católica e a Frente Agrária Paranaense (FAP)
}

\author{
Angelo Priori \\ Luciana Regina Pomari \\ Silvia Maria Amâncio \\ Veronica Karina Ipólito
}

\section{SciELO Books / SciELO Livros / SciELO Libros}

PRIORI, A., et al. História do Paraná: séculos XIX e XX [online]. Maringá: Eduem, 2012. A Igreja Católica e a Frente Agrária Paranaense (FAP). pp. 179-198. ISBN 978-85-7628-587-8. Available from SciELO Books $<$ http://books.scielo.org $>$.

\section{(1) $(1)(2)$}

All the contents of this chapter, except where otherwise noted, is licensed under a Creative Commons Attribution-Non Commercial-ShareAlike 3.0 Unported.

Todo o conteúdo deste capítulo, exceto quando houver ressalva, é publicado sob a licença Creative Commons Atribuição Uso Não Comercial - Partilha nos Mesmos Termos 3.0 Não adaptada.

Todo el contenido de este capítulo, excepto donde se indique lo contrario, está bajo licencia de la licencia Creative Commons Reconocimento-NoComercial-CompartirIgual 3.0 Unported. 


\section{3 \\ A Igreja Católica e a Frente Agrária Paranaense (FAP)}

\section{O surgimento da FAP}

O Norte do Estado do Paraná apresenta um processo histórico, riquíssimo de acontecimentos que merecem ser conhecidos e estudados pela juventude e pelos profissionais da área da educação. Um desses processos é a formação da Frente Agrária Paranaense, uma organização social de cunho sindical, organizada pela Igreja Católica, que tinha como objetivo combater o ideário comunista e competir com o Partido Comunista na estruturação de sindicatos e associações de trabalhadores rurais.

A Igreja Católica, desde o final do século XIX, vinha acumulando alguma experiência na estruturação de organizações sociais de trabalhadores, influenciada, principalmente, pela publicação da encíclica papal Rerum Novarum, do Papa Leão XIII, no ano de 1891.

Essa encíclica e todo o debate ocorrido no interior da Igreja a partir da sua publicação estimularam a instituição religiosa a 'educar os trabalhadores na fé cristã e na ordem' (DE SANTCTIS, 1972). Mas, para educar, era necessário criar as condições para isso. Foi com esse espírito que, no Brasil, a partir de 1932, foram criados os Círculos Operários, a Ação Católica, a Ação Católica Rural e a Juventude Operária Católica. 
O braço estadual da Ação Católica Rural foram as Frentes Agrárias, que se disseminaram por todo o país no início dos anos 1960. No Paraná, a Frente Agrária Paranaense (FAP) foi articulada pelos bispos de Londrina, Jacarezinho, Maringá e Campo Mourão, com o objetivo de 'proporcionar condições mais humanas de vida na lavoura'. Eram, respectivamente, bispos dessas cidades: Dom Geraldo Fernandes, Dom Geraldo de Proença Sigaud, Dom Jaime Luiz Coelho e Dom Eliseu Mendes.

Em entrevista à Folha de Londrina, o Padre Marconi Montezuma, porta-voz da diocese de Londrina, comentava como surgira a ideia de formar uma Frente Agrária no Paraná e por que esta deveria ser lançada e sediada no Norte do Paraná. Segundo o porta-voz, o mentor intelectual da Frente Agrária Paranaense (FAP) foi o Arcebispo de Londrina, Dom Geraldo Fernandes:

foi quem deu o primeiro grito, bateu a fotografia da paisagem roxa nas andanças pastorais, estabeleceu as coordenadas, craneou o movimento, codificou, formulou a estrutura dos estatutos. E os demais bispos do Paraná, que já sentiam as mesmas necessidades, adotaram a linha da conduta, uniforme para todo o Estado. E aí está o rolo compressor, aplainando o terreno para a marcha de uma frente pacífica, mas terrivelmente disposta a cristalizar a verdade agrária (FOLHA DE LONDRINA, 1961a, p. 3).

O 'rolo compressor' da Igreja Católica tinha um destino certo. Açambarcar o movimento de trabalhadores rurais, visando 'cristalizar a verdade agrária', a fim de privar os comunistas da expectativa de dominar esse movimento. Para que a FAP pudesse ter sucesso na sua missão, o melhor seria instalar o seu Conselho Geral, na cidade-embrião do movimento subversivo no Paraná, isto é, Londrina. E, para destruir a influência dos comunistas no movimento dos trabalhadores rurais, a FAP se utilizou das mesmas estratégias daqueles: a organização institucional. Segundo o Padre Marconi Montezuma: 
Há quem pondere que não devemos substimar a subversão que ensaiam em nosso meio. Compreendo. Mas usar as palavras deles apresentando soluções imediatas, como vamos fazer, é coisa com que eles não contavam na região (FOLHA DE LONDRINA, 13 ago. 1961a, p. 3).

Nessa estratégia de destruir a influência dos comunistas entre os trabalhadores rurais, a Frente Agrária Paranaense propunha organizar toda uma infraestrutura que possibilitasse aos mais variados meios:

1. Formar lideranças regionais e locais;

2. Estudar os problemas locais, levando as reivindicações para o cotejo do Estado;

3. Realizar debates e conferências para formar a mentalidade cristã na fé e na ordem;

4. Instalação de uma emissora de rádio para a educação dos trabalhadores rurais e a divulgação da FAP;

5. Formação da opinião pública para uma autêntica solidariedade cristã;

6. Instalação de departamentos técnicos, judiciais e de assistência médica;

7. Criação de associações profissionais que se transformariam em sindicatos (ALVARENGA, 2008).

Entre os meios acima, o mais importante, no nosso entendimento, foi a decisão de se criar associações profissionais, com vistas a transformálas em sindicatos. De certa forma, essa preocupação vai ao encontro da Encíclica Mater et Magistra, publicada pelo Papa João XXIII em 15 de maio de 1961, que estimulava a organização dos trabalhadores do campo em sindicatos (PRIORI, 1997). A visão que a FAP tinha dos sindicatos, no entanto, era consoante à visão conservadora, majoritária no seio da Igreja no início dos anos 1960, ou seja, de se preservar a ordem estabelecida legalmente, conforme as palavras do padre Marconi Montezuma:

Os sindicatos serão arregimentados, treinados e utilizados como instrumentos de reivindicação coletiva para os casos em que o planejamento técnico não convencer ou falhar 
a lógica da força do direito (FOLHA DE LONDRINA, 1961a, p. 3).

A divulgação da campanha pró-FAP repercutiu célere entre os fazendeiros da região Norte do Paraná. Muitos deles destinavam grandes quantias em dinheiro para a campanha, outros procuravam estimular os seus empregados para integrar a campanha, dissuadindo-os de se associarem aos sindicatos de trabalhadores rurais influenciados por 'elementos subversivos'. Um dos fazendeiros, numa conversa com o bispo de Londrina, afirmava: "o senhor contará com $60 \%$ dos homens de bem. Isso vai ser uma força impressionante, política e social. Um rolo compressor mesmo" (FOLHA DE LONDRINA, 1961a, p. 3).

O próprio porta-voz da diocese de Londrina proclamava na imprensa o sucesso da campanha pró-FAP. Dizendo ter percorrido mais de 30 municípios da região, prognosticava:

Noventa por cento das forças vivas do campo estão conosco. Faltava apenas um grito, um elo aglutinador. Estou vibrando com o grau de 'politização' do elemento do campo no Norte do Paraná (FOLHA DE LONDRINA, 1961a, p. 3).

A Frente Agrária Paranaense foi fundada em 13 de Agosto de 1961, na cidade de Maringá, durante uma missa campal realizada em frente à catedral. Teve vida efêmera, desaparecendo em 1968, após a 'pena de morte' imposta aos movimentos sociais pelo golpe militar de 1964 e pelo Ato Institucional número 5 (AI-5). Como surgiu para combater os sindicatos de trabalhadores rurais formados pelo PCB, que, no Paraná, foram os que mais sofreram as perseguições do regime instalado em 1964, a Frente Agrária Paranaense sucumbiu com a impressão do 'dever cumprido' (SERRA, 1991).

O geógrafo Elpídio Serra, analisando a atuação da Igreja Católica e da Frente Agrária Paranaense no movimento social rural do Norte do Paraná, ponderou: 
A) A Igreja se mantinha no Paraná radicalmente contra a reforma agrária ou qualquer outro tipo de alteração na estrutura fundiária tradicional. Justificava que a reforma iria comprometer o direito de propriedade que no caso do Norte do Paraná, tomado como exemplo pelo clero, havia sido adquirido com muitos sacrifícios pelo agricultor pioneiro. A propriedade da terra, como direito adquirido, era colocado como fator de estabilidade da família cristã. [...] A propriedade da terra e a família se completavam: quebrar esta unidade significava subversão da ordem, que a igreja queria evitar.

B) Muito mais do que ser contra a reforma agrária, era contra a infiltração nos movimentos camponeses por parte de alguma força política que não se afinava com os interesses da hierarquia católica (SERRA, 1991, p. 283-284).

A primeira consideração do Professor Serra justifica-se pelas diversas exigências que a FAP solicitava na hora de o trabalhador rural se associar a um sindicato controlado por ela. Para se filiar aos sindicatos, influenciados pela Frente Agrária Paranaense, os trabalhadores deveriam provar que eram proprietários das terras que cultivavam, ou então, no caso de ser parceiros ou arrendatários, apresentar os contratos assinados pelos proprietários das terras. Não se aceitava a associação de trabalhadores temporários ou permanentes que mantinham apenas a relação de trabalho assalariado com o patrão. Essas exigências só vieram reforçar a luta que a Igreja travara para evitar o rompimento da relação família-propriedade, sendo, dessa forma, contra a reforma agrária.

A segunda consideração do professor, de certa forma, é um desdobramento da primeira. Ao mesmo tempo em que a Igreja lutava contra outras 'forças políticas' que viessem a se 'infiltrar nos movimentos camponeses', lutava contra a influência comunista e diretamente contra a proposta de reforma agrária. No entanto, os sindicatos de trabalhadores rurais do Norte do Paraná, influenciados pelo PCB, estavam muito mais preocupados em direcionar a luta para conquistar melhores salários e uma 
legislação trabalhista para o campo, do que propriamente com o projeto de reforma agrária.

Visando ampliar sua influência entre os trabalhadores e propagandear suas ideias, em 27 de setembro de 1962, a Frente Agrária Paranaense fundou o seu próprio jornal: a Folha do Norte, editado em Maringá, sob a responsabilidade da diocese da cidade e distribuído para toda a região. A fundação do jornal, um ano após o lançamento da FAP, segundo o editorial do primeiro número, tinha o objetivo de "condenar a ameaça comunista e os sindicatos fundados com o apoio do governo" (FOLHA DO NORTE, 1962, p. 2).

Dois anos após a sua fundação, a FAP fazia o primeiro balanço, publicando que já havia organizado, em todo o Norte do Paraná, 30 sindicatos, embora nenhum dos sindicatos organizados tivesse sido reconhecido pelo Ministério do Trabalho. Em 11 de agosto de 1963, publicando matéria no jornal da FAP, o bispo de Maringá, Dom Jaime Luiz Coelho, protestava e conclamava o povo a protestar contra o Ministério do Trabalho, pois este, "com criminosa parcialidade ideológica" reconhecia os sindicatos comunistas e se negava a reconhecer os "sindicatos rurais organizados pela FAP” (FOLHA DO NORTE, 1963, p. 2). Na verdade, a maioria dos sindicatos de trabalhadores reconhecidos no Norte do Paraná nos anos de 1962 e 1963 eram influenciados pelo PCB ou pelos populistas. Não é por menos que a Frente Agrária Paranaense, apoiada pelos empregadores rurais, desenvolvia uma política de hostilidade contra o Governo João Goulart e seu Ministro do Trabalho. Entretanto, com a queda de Goulart e a ascensão do regime militar, quem mais se beneficiou foi a Igreja: patrões deram cabo de várias organizações camponesas. Contudo, no que tange ao sindicalismo, mesmo quando houve intervenções em sindicatos localizados, a Igreja, via de regra, pôde indicar substitutos recrutados entre seus quadros mais moderados, evitando que parte significativa deles fosse fechado (NOVAES, 1991, p. 176). 


\section{O II Congresso de trabalhadores rurais: batalha campal pela hegemonia do movimento}

O II Congresso de Lavradores e Trabalhadores Rurais do Paraná foi realizado na cidade de Maringá nos dias 13, 14 e 15 de Agosto de 1961, um ano após o I Congresso, realizado na cidade de Londrina. O objetivo central do Congresso era a preparação dos trabalhadores paranaenses para o I Congresso da União dos Lavradores e Trabalhadores Agrícolas do Brasil (ULTAB), que se realizaria no mês de novembro do mesmo ano em Belo Horizonte.

Ao contrário do Congresso de Londrina, marcado por uma discussão tranquila e pacífica, no Congresso de Maringá o processo foi tumultuado e violento. $\mathrm{O}$ tumulto e a violência ocorreram pela coincidência (não tão coincidente assim) do lançamento da Frente Agrária Paranaense, que se realizou na cidade de Maringá, nos mesmos dias do Congresso (FOLHA DE LONDRINA, 1961b).

Participaram desse congresso mais de 2.000 delegados oriundos de todo o Estado do Paraná. Mais uma vez, diversas autoridades locais, bem como deputados estaduais e federais estiveram presentes. O Presidente da República, Senhor Jânio Quadros, fez-se representar por meio do Líder na Câmara, Deputado Nestor Duarte (JORNAL TERRA LIVRE, 1961). Estiveram presentes, ainda, Francisco Julião, líder das Ligas Camponesas do Nordeste, e diversos diretores nacionais da ULTAB.

Para se ter uma ideia da importância desse congresso, transcrevemos abaixo o teor do telegrama enviado pelo Presidente Jânio Quadros aos congressistas, pois o mesmo, além de revelar o pensamento presidencial em relação aos problemas rurais, ganhou importância significativa por ter sido redigido 13 dias antes de sua renúncia ao cargo máximo do país. Diz o telegrama, publicado no Jornal Terra Livre:

As reivindicações dos trabalhadores rurais - Reforma Agrária, extensão das leis sociais ao campo, assistência à 
produção agrícola - estão incorporadas ao programa de governo. Considero-as essenciais, não só do ponto de vista da justiça social como do ângulo do interesse geral da economia do país. Constituem compromisso básico, que assumi nas praças públicas com as multidões anônimas. Realizá-las é o meu dever e, a esta altura, das preocupações fundamentais do meu governo.

Peço aos camponeses do Paraná - colonos, assalariados, percenteiros, meeiros e pequenos proprietários - que se reúnem agora em Maringá, que ajudem o governo, formulando sugestões objetivas que possam ser imediatamente incorporadas aos estudos e providências em curso para a reforma estrutural da vida e da produção agrária no Brasil.

Declaro a participação no encontro de Maringá serviço público relevante e aguardo, ansioso e confiante, sua colaboração ao governo (JORNAL TERRA LIVRE, 1961, p. 12).

Entre os pontos mais polêmicos discutidos no II Congresso, estava a questão da Reforma Agrária, uma das prioridades entre as reivindicações dos trabalhadores presentes. Os trabalhadores rurais consideravam que "tanto os problemas dos assalariados como a dos posseiros só poderiam ser resolvidos com a liquidação do latifúndio” (SIGAUD, 1981, p. 6). Entre outros pontos discutidos, estavam a necessidade imediata da aplicação da legislação social ao campo, a plena liberdade de sindicalização, o pagamento efetivo do salário mínimo, a abolição de toda forma de pagamento por meio de 'vales' e 'barracão', a abolição de todo trabalho gratuito, entre outros.

Concomitante ao Congresso, no dia 13 de agosto de 1961, foi realizada, em frente à catedral de Maringá, uma missa campal, celebrada pelos bispos de Londrina, Maringá, Jacarezinho e Campo Mourão, lançando oficialmente a Frente Agrária Paranaense. Nessa Missa, que, segundo estimativas do Jornal Folha de Londrina, estiveram presentes 10.000 pessoas, o bispo de Londrina, Dom Geraldo Fernandes, fez uma referência ao II Congresso, condenando a presença de parlamentares e de outras autoridades: 
Os organizadores da FAP manifestam repúdio àqueles que prestigiam os congressos comunistas e vêm depois juntarse a nós, em reuniões cristãs e democráticas, como esta concentração. É preciso estabelecer ampla diferenciação entre os verdadeiros democratas e os comunistas ateus (FOLHA DE LONDRINA, 1961b, p. 5).

A Igreja Católica do Paraná procurou intervir de todas as formas para que o Congresso dos trabalhadores não pudesse acontecer. Desde a habitual acusação de 'comunistas' até pedidos à polícia e aos poderes públicos constituídos, no sentido de estes impedirem o Congresso. No entanto, o reforço policial e os ânimos apaziguadores dos organizadores do II Congresso indicavam que as duas manifestações iriam acabar sem nenhum entrevero. O próprio jornal Folha de Londrina, desfazendo as expectativas, falava desse ânimo pacifista:

A partir do momento que se anunciou a realização da última [lançamento da FAP] em data coincidindo com a primeira [II congresso], principiou-se, em vários círculos, o temor pela ocorrência de conflitos, facilmente motiváveis em provocações eventualmente partidas de um ou outro grupo [...] o ânimo pacifista manifestado pelos congressistas reunidos esta noite dissipou as apreensões, pelo menos até agora (FOLHA DE LONDRINA, 1961a, p. 3).

Porém, não foi o que aconteceu no dia seguinte. Na noite de 14 de agosto, a organização do Congresso havia estipulado um recesso, permitindo, aos congressistas e autoridades presentes, uma noite de lazer e descontração. Aproveitando-se dessa oportunidade, nessa mesma noite $\mathrm{o}$ auditório onde estava sendo realizado o Congresso foi invadido. $\mathrm{O}$ jornal comunista Terra Livre, que cobria o Congresso, foi taxativo em suas reportagens:

Mas como não houvesse sessão plenária na noite do dia 14, os bispos aproveitaram a ausência da polícia e dos congressistas e ajudados por alguns jagunços contratados, arrombaram a porta de aço do prédio do congresso, 
quebrando cadeiras, danificando material fotográfico e documentos, rasgando faixas onde se lia 'reforma agrária' (JORNAL TERRA LIVRE, 1961, p. 12).

No dia seguinte, mais de 2.000 manifestantes se reuniram nas ruas centrais de Maringá, portando cartazes de repúdio ao 'comunismo', às ligas camponesas e ao congresso. Essa multidão apareceu inicialmente defronte ao edifício em que estava sendo realizado o congresso, mas como este havia sido suspenso momentaneamente, em decorrência do ataque noturno anterior e do ambiente hostil "que ia se tornando a cada hora mais tenso", deslocou-se em passeata pelas ruas da cidade (FOLHA DE LONDRINA, 1961b, p. 5).

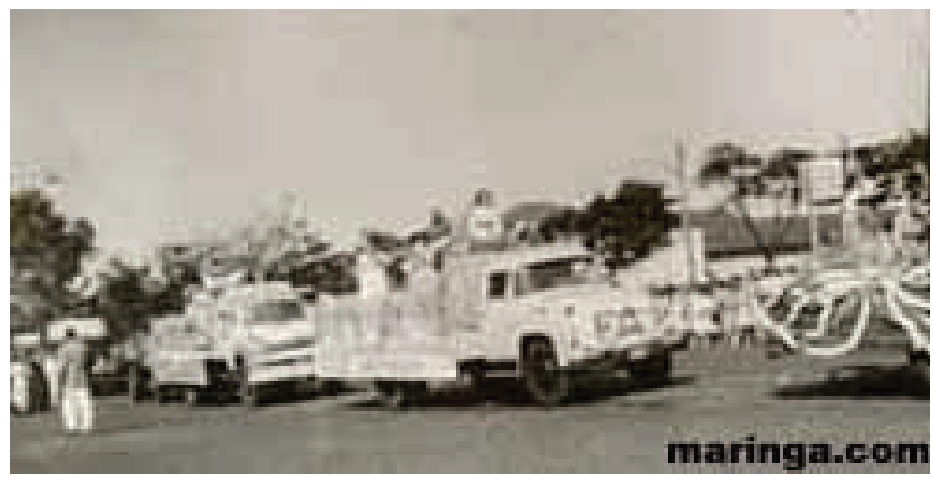

Figura 1: Passeata realizada pela FAP Fonte: Alvarenga (2008, p. 83).

Segundo os jornais Folha de Londrina e Terra Livre, esses manifestantes eram estudantes das escolas católicas de Londrina, Maringá e Apucarana, que, por meio de ônibus fretados pelas dioceses, foram deslocados para Maringá com o intuito de protestarem contra a realização do II Congresso de Trabalhadores Rurais (FOLHA DE LONDRINA, 1961b; TERRA LIVRE, 1961). O Padre Orivaldo Robles lembra o fato com bastante acuidade: "numa época de nervos à flor da pele, não houve como evitar o choque entre representantes da Igreja - padres, congregados 
marianos, alunos do colégio católicos - e militantes do Partidão. A polícia foi chamada" (ROBLES, 2007, p. 200).

Segundo informações de Antonio de Lima Sobrinho, um antigo diretor da União dos Trabalhadores de Londrina (UTL), que esteve presente no Congresso, só não houve um confronto direto entre os congressistas e os manifestantes da Frente Agrária Paranaense, porque a polícia, garantindo a segurança do representante do Presidente Jânio Quadros, interveio, procurando dispersar com jatos de água a multidão de manifestantes. Assim mesmo, houve diversos atritos entre a polícia e os estudantes, havendo, inclusive, vários disparos no meio da multidão. Um dos manifestantes ("não se sabe se era estudante ou jagunço") disparou "dois tiros de revólver contra uma das viaturas da polícia, atingindo o pára-brisas do veículo” (FOLHA DE LONDRINA, 1961b, p. 5).

Quando os ânimos se acalmaram e a força policial foi reforçada com o pelotão de Apucarana, os congressistas retomaram os trabalhos, não disfarçando a melancolia de seus rostos e de seus discursos. O presidente dos trabalhos, Senhor Nestor Veras, (Secretário da ULTAB), retomando as atividades, propôs aos congressistas que se enviasse um telegrama de protesto ao Papa João XXIII, informando dos acontecimentos causados pelos representantes da Igreja. Proposição aceita, o telegrama votado no II Congresso e enviado ao Papa tinha o seguinte teor:

Trabalhadores Rurais do Estado do Paraná, Brasil, reunidos em Maringá, no II Congresso, pacificamente, para tratar de urgentes problemas sociais ligados à sua classe, protestam energicamente contra sacerdotes católicos desta região, que ameaçam o conceito de religião, insuflando menores, causando depredações, assalto à sede do congresso, tentando impedir a realização do conclave. Conhecendo a opinião de Vossa Eminência com respeito às questões agrárias contida na encíclica MATER ET MAGISTRA, citada neste congresso, esperamos providências de sua santidade no sentido de coibir os abusos dos representantes da igreja nesta região (PRIORI, 1997, p. 211). 
Se o Papa recebeu o telegrama e tomou alguma providência a respeito dos acontecimentos, não tivemos condições de saber. Fica, no entanto, a certeza de que aqueles foram anos conturbados, quando o espaço da luta social era disputado com muito rigor. E que cabe ao historiador preservar essa memória, não esquecida, mas ignorada.

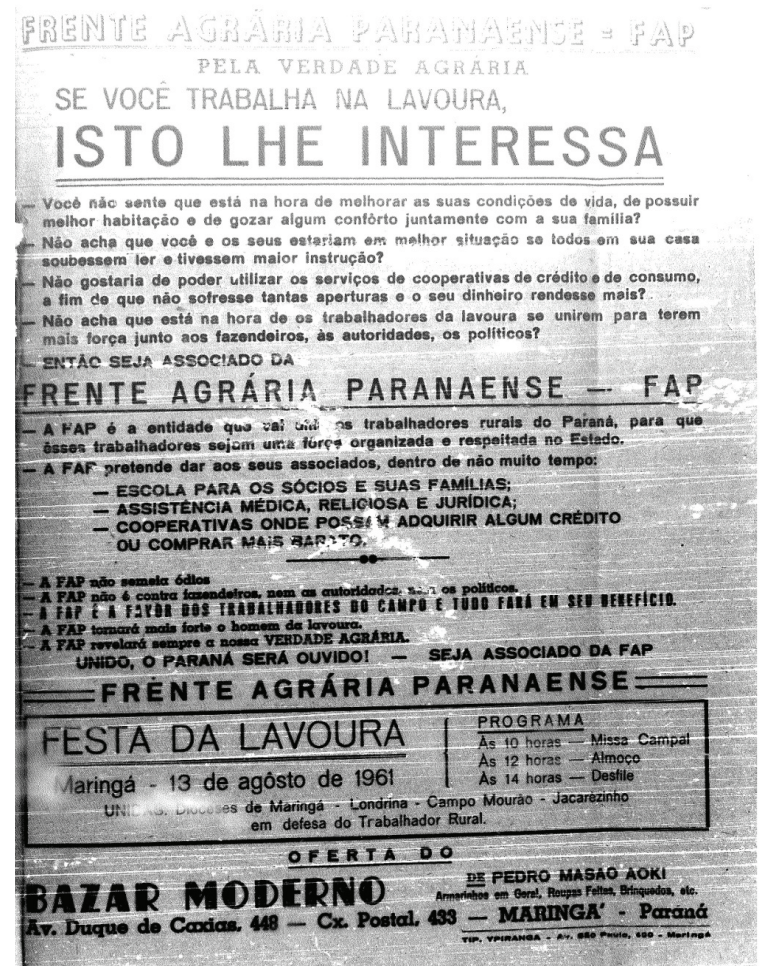

Figura 2: Panfleto de orientação aos trabalhadores Rurais sobre a FAP e convite para a fundação da entidade em Maringá

Fonte: Alvarenga (2008).

\section{As estratégias de consolidação da FAP}

A atuação da Igreja Católica no Norte do Paraná, nas décadas de 1950 e 1960, deve ser entendida a partir da postura que esta instituição assumiu frente ao avanço comunista. A fundação da FAP tinha esta 
intenção clara: combater o comunismo e a ação política dos militantes comunistas. Mas o combate ao comunismo, bem como às atividades dos militantes comunistas, deveria ocorrer de forma concreta, com ações que pudessem tocar os corações e mentes da população rural trabalhadora. E, nesse caso, a luta contra as injustiças sociais, a melhoria das condições de vida do homem do campo, o direito à sindicalização, o direito às leis trabalhistas, as reivindicações por preços justos na hora de vender os produtos eram iniciativas que coadunavam com os interesses dos homens do campo.

Por meio de manifestações, reivindicações e protestos, os dirigentes da FAP apareciam para a sociedade como defensores dos interesses sociais e dos direitos trabalhistas dos trabalhadores rurais. Ao mesmo tempo, a FAP cuidava de organizar o maior número de sindicatos possíveis, diminuindo a ação dos comunistas entre os trabalhadores rurais.

Em função do avanço comunista, pontuou o Padre Marconi Montezuma, para os dirigentes da Igreja "já não era mais suficiente caminhar ao lado dos camponeses" e sim era o momento de "caminhar na frente" (FOLHA DE LONDRINA, 1961a). Os bispos e os padres se tornaram verdadeiros porta-vozes dos trabalhadores rurais, direcionando suas ações e reivindicações politicamente. O sociólogo Osvaldo Heller da Silva considera que, ao criar a FAP, os bispos se colocaram como representantes dos lavradores católicos na região, como verdadeiros 'amigos legítimos dos trabalhadores'. Sobre esse fato o autor considera:

Representando o campesinato, o clero podia defender a existência do grupo de lavradores enquanto força política, a partir de então portadores de uma voz política. O episcopado se apropriou, ao mesmo tempo, da palavra e da força desse grupo (SILVA, 2006, p. 229).

Para destruir a influência dos comunistas no movimento dos trabalhadores rurais, a entidade se utilizou das mesmas estratégias do PCB: a organização institucional. Na diocese de Maringá, nos quatro primeiros 
anos de existência da FAP, conseguiu-se registrar como sindicalizados uma média de 150.000 trabalhadores rurais, com aproximadamente 30 sindicatos organizados. Dessa forma os religiosos consideravam que os sindicatos cristãos constituíam-se enquanto forma de pregar a 'pacificação do meio rural' entre o 'empregado e o patrão', satisfazendo os interesses de ambos. Para fortalecer o sindicalismo rural, houve a criação das Cooperativas como 'alternativa segura de comercialização de seus produtos'.

Em 1964, a FAP fundou a Cooperativa Agrícola de Maringá. Outras 37 cooperativas foram fundadas em 37 municípios da região. Com a criação das cooperativas, a Igreja Católica construiu uma representação significativa no meio rural, dinamizando ainda mais o sindicalismo rural católico no Norte do Paraná (ALVARENGA, 2008).

Além das cooperativas, a FAP construiu e aplicou seu discurso social e político na defesa da legislação social. As ações orientadas pela FAP provocaram uma série de encontros e debates que envolveram os trabalhadores rurais, empregados, sindicalistas, advogados, magistrados da Justiça, padres e a imprensa acerca da legislação social e da formação dos sindicatos rurais.

Para a FAP, a conquista dos direitos trabalhistas inerentes ao processo do trabalho e da luta pela sobrevivência em busca de melhores condições de vida não significava somente reparar algumas injustiças sociais cometidas por seus patrões, significava, também, a construção de uma identidade social por parte dos trabalhadores rurais que se posicionariam contra a prática e orientação comunista.

A Igreja se colocava diante de um processo de mobilização e formação de uma identidade representativa dos trabalhadores rurais. Enquanto orientadora dos agentes sociais envolvidos no meio rural, lançava um discurso, posicionando-se contra as condições de exploração do trabalho que excluía aqueles da legislação trabalhista. Essa atitude fazia parte da construção de uma imagem social, enquanto 'legítima defensora do meio rural'. 


\begin{abstract}
A situação atual da lavoura é de angustiosa incerteza. Se o grande lavrador debate-se diante de perspectivas alarmantes, bem alarmantes, bem pode imaginar a situação do pequeno lavrador. Se não tem grandes aspirações na vida, contudo, falta-lhe a recompensa do seu trabalho curtido a um sol causticante e sob uma poeira de enervar. Acresce a falta de assistência, por quem de direito. De condições mais humanas de vida, o que leva ao êxodo dos campos. Será sempre ele, o pequeno lavrador, o maior prejudicado na inconsistência de preços e mercados que flutuam á mercê de conjunturas não aplausíveis (ARQUIVO FAP, 1963).
\end{abstract}

A FAP agiu estrategicamente, construindo imagens negativas em relação aos sindicatos comunistas, enfatizando o perigo dessa ameaça diante da 'inocência dos trabalhadores'. Essas atitudes eram decorrentes de uma conjuntura nacional e internacional em que a própria entidade estava envolvida. A estratégia da entidade era a de eliminar a influência dos comunistas entre os trabalhadores rurais e consistia também em organizar estruturalmente os sindicatos, garantindo a formação de outros núcleos sindicais. Assim, em seus comunicados, sempre enfatizava a necessidade de 'promover a união da classe' para que esta buscasse a 'defesa dos seus direitos'.

A imprensa era o mecanismo principal de estímulo à constituição de organizações e de mobilizações. Em Londrina, o Bispo Dom Geraldo Fernandes utilizava-se de uma emissora de rádio para fazer a divulgação do movimento. Outros aliados importantes foram os jornais Folha de Londrina e O Estado do Paraná, que publicavam constantes notícias, ressaltando os feitos da FAP e denunciando as atividades de militantes comunistas. Portanto, os meios de comunicação atingiam não só os trabalhadores rurais mas também se refletiam em um alerta às possíveis ações do partido comunista.

O sociólogo Osvaldo Heller da Silva (2006) classificou essa atitude da Igreja como um 'combate simbólico', em que os religiosos procuraram impor suas 'representações sociais' no sentido de classificar os adversários a partir de 'qualificativos políticos, ideológicos e até morais'. É evidente 
que o Partido Comunista também se utilizava de um contra-argumento, procurando alertar seus militantes para o perigo que esse uso dos meios de comunicação representava para os seus interesses.

Segundo o Partidão, a rádio católica confundia as 'bases', quer dizer, ela apresentava a sua divisão do mundo social, classificando-o como legítimo, mas diametralmente oposto àquela dos comunistas. De fato, divulgando a sua opinião por meio da mídia, os líderes católicos queriam 'forma a opinião' (SILVA, 2006, p. 235).

Se os religiosos utilizavam diversos recursos simbólicos para impor suas representações sociais, talvez o que teve maior repercussão foi a fundação de um jornal, pela Diocese de Maringá. Visando ampliar sua influência entre os trabalhadores e propagar suas ideias, em 27 de setembro de 1962, a Frente Agrária Paranaense fundou o seu próprio jornal: a Folha do Norte do Paraná. Este jornal se tornou o espaço mais comum utilizado para divulgar a campanha da FAP, bem como de suas ideias e denúncias. Assim, o jornal foi uma ferramenta fundamental para o desenvolvimento da campanha de solidificação dessa entidade e para as denúncias contra o movimento comunista que naqueles anos alcançava grande proporção.

Outro ponto importante de comunicação da FAP com os trabalhadores rurais foram os panfletos e pequenos escritos. Pesquisas de opinião indicavam que somente $2 \%$ da população nacional liam alguma publicação regularmente e que apenas 7\% se preocupavam em acompanhar editoriais e artigos conjunturais nos jornais. No entanto, essas mesmas pesquisas indicavam que $47 \%$ das pessoas que recebiam um folheto ou uma publicação de uma página na região Norte do Paraná a liam; 35\% aproveitavam relativamente bem seu conteúdo, desde que adequado às suas condições específicas. Nesse sentido, a redação de pequenos folders ou panfletos, geralmente distribuídos após as missas, tinham uma repercussão importante na divulgação e na aproximação dos trabalhadores com a FAP. 
Segundo a FAP, essa disposição popular não foi conseguida por 'milagre', nem por 'acaso'; era fruto de longos e árduos anos de formação, orientação, esclarecimento e informação democrática. Segundo a entidade, foi a partir de um trabalho continuado, 'sistemático e racional', realizado por vários grupos diferentes numa 'luta desigual, inglória', que essa entidade alcançou o ‘êxito deste trabalho’. Dessa forma a FAP sentia que, sem a prática da divulgação de suas realizações e orientações por meio dos jornais e de panfletos, era impossível consolidar a sua atuação, 'tão ansiosamente esperado por todos e tão dificilmente conquistado'.

\section{O desfecho da atuação da FAP}

Com o golpe militar a corrida pela criação de novos sindicatos deixou de existir. A ação repressiva do governo civil-militar pôs fim ao avanço comunista em todo o país. A disputa pelo controle sindical no Norte do Paraná foi encerrada. Para os religiosos, após a desarticulação do movimento comunista no meio rural, principal objetivo da entidade católica, suas atividades foram aos poucos terminando.

No Paraná as perseguições que se deram como formas de repressão foram por meio da violência física. Não só os dirigentes do PCB, mas também os trabalhadores rurais, foram vítimas da violência. Segundo Palmeira (1985, p. 45), a repressão contra os lideres sindicais rurais foi mais forte que a sentida pelos operários e outros setores do meio urbano, pois o Estado agiu de forma direta, intervindo no meio rural, e permitindo a ação das milícias privadas.

Outra forma de repressão desenvolvida contra os sindicatos rurais foram os incêndios criminosos, muitos incentivados por fazendeiros e pessoas comuns que defendiam o golpe militar. No Norte do Paraná, vários sindicatos foram incendiados, como em Nova Esperança, Astorga, Cianorte e Terra Boa. Em Cruzeiro do Oeste, um policial exaltava a boa "intenção da população" em depredar e incendiar as sedes dos sindicatos 
rurais, enquanto que, em Mandaguari, a polícia apreendia "farto material de ideologia comunista" no sindicato rural local, como forma de conter os "exaltados" que desejavam promover quebra-quebras (SILVA, 2006, p. 281).

Assim, o golpe militar de 1964 mudava o cenário dos movimentos sociais rurais no Norte do Paraná. Todos os sindicatos que tinham alguma influência do Partido Comunista sofreram algum tipo de intervenção. Para se ter uma ideia, em 1964 os comunistas tinham 82 sindicatos de trabalhadores rurais organizados no Estado do Paraná (COSTA, 1996), contra 46 da FAP.

Em comparação ao desenvolvimento sindical católico, percebemos que os sindicatos comunistas, apesar de terem suas atividades totalmente eliminadas após o golpe militar, alcançaram um número maior de organizações sindicais registradas e atuantes no Norte do Paraná até 1964. Essa comparação torna-se importante no sentido de se entender que, em função do avanço sindicalista de esquerda, surgiu um verdadeiro impulso organizacional da Igreja Católica. Cabe ressaltar que, desde a década de 1950, o comunismo já atuava na organização dos trabalhadores rurais e somente no período de 1960 a Igreja Católica entrava na disputa pelo controle sindical.

Para a FAP, o triunfo do golpe de 1964 (chamada pela entidade de 'revolução') representou o fim das 'forças destruidoras da ordem e da paz social'. O Bispo D. Jaime afirmava que nesse processo político nacional 'desapareceram ou se ocultaram' a movimentação comunista, porém, a 'doutrinação para o bem continuou'. Dessa maneira, a entidade não via mais a necessidade de grandes concentrações de trabalhadores rurais em movimentos contra o comunismo (ALVARENGA, 2008).

Com o golpe militar de 1964, mudava-se todo o panorama de disputa travada pela Igreja Católica contra o comunismo no Norte do Paraná. A FAP aos poucos ia diminuindo suas atuações junto aos trabalhadores rurais, alcançando seu término em 1969. 
Ao terminar este texto, cabe-nos afirmar que, se aqueles foram anos conturbados, pelo menos tivemos uma intensa participação e discussão em torno dos trabalhadores rurais. Excluídos da política e da cidadania até os anos 1950, estes surgiram com um vigor e uma aparente capacidade de organização social jamais conhecida, até então, na história do Brasil. Sem dúvida, em que pesem as diferenças e as disputas ideológicas, traduzidas muitas vezes em confrontos e violências, a Igreja Católica e o Partido Comunista Brasileiro (PCB) tiveram importância fundamental no processo organizatório dos trabalhadores rurais da década de 1960. É uma pena que essa disputa tivesse sido acoimada pelo insano golpe militar de 1964, para alívio de uns e desespero de muitos.

\section{Referências}

ALVARENGA, S. C. A. A atuação da Igreja Católica no processo de organizaçãa dos sindicatos de trabalhadores rurais do Norte do Paraná-1960/1969: o caso da Frente Agrária Paranaense. Maringá, 2008. 148 f. Dissertação (Mestrado em História) - UEM, Maringá, 2008.

ARQUIVO FAP. Boletim do Movimento de Orientação Rural, n. 13, 1963.

COSTA, L. F. C. Sindicalismo rural brasileiro em construção. Rio de Janeiro: Forense, 1996.

FOLHA DE LONDRINA. Londrina, 13 ago. 1961a.

FOLHA DE LONDRINA. Londrina, 15 ago. 1961 b.

FOLHA DO NORTE. Maringá, 27 set. 1962.

FOLHA DO NORTE. Maringá, 11 ago. 1963.

JORNAL TERRA LIVRE. Maringá, n. 102, ago. 1961.

PALMEIRA, M. Diversidades das lutas sociais no campo. In: PAIVA, V. (Org.). Igreja e questão agrária. São Paulo: Edições Loyola. 1985. p. 25-45.

PRIORI, A. Movimentos sociais camponeses: a luta entre o partido comunista e a Igreja Católica pela hegemonia sindical no Brasil: 1954-1964. Solar. Estúdios Latino Americanos, Santiago, v. 10, p. 203-215, 1997.

ROBLES, O. A Igreja que brotou da mata: os cinqüenta anos da Diocese de Maringá. Maringá: Dental Press, 2007. 
SERRA, E. Processos de ocupação e a luta pela terra agrícola no Paraná. 1991. 361 f. Tese (Doutorado em Geografia) - IGCE/UNESP, Rio Claro, 1991.

SILVA, O. H. A foice e a cruæ: comunistas e católicos no sindicalismo dos trabalhadores rurais do Paraná. Curitiba: Rosa de Bassi, 2006.

NOVAES, R. R. Continuidades e rupturas no sindicalismo Rural. In: BOITO JR., Armando et al. O sindicalismo brasileiro nos anos 80. Rio de Janeiro: Paz e Terra, 1991. p. 171-185.

SIGAUD, L. Congressos Camponeses. Reforma Agrária, Campinas, v. 11, n. 1, p. 1-8, 1981. 